\title{
Extent of underdiagnosis of familial hypercholesterolaemia in routine practice: prospective registry study
}

\author{
H A W Neil, T Hammond, R Huxley, D R Matthews, S E Humphries
}

Oxford Centre for Diabetes,

Endocrinology and Metabolism,

Radcliffe Infirmary Oxford OX2 6HE

H A W Neil physician

D R Matthews

consultant physician

Division of Public

Health and Primary

Health Care,

Institute of Health

Sciences, University

of Oxford, Oxford

OX3 7LF

T Hammond

research assistant

R Huxley

research officer

Centre for

Cardiovascular

Genetics, Rayne

and University

College London

Medical School,

London WC1E 6JJ

S E Humphries

professor of

cardiovascular

genetics

Correspondence to: H A W Neil

andrew.neil@dphpc.

ox.ac.uk

BMJ 2000;321:148 honorary consultant

Institute, Royal Free

In heterozygous familial hypercholesterolaemia the cumulative risk of a fatal or non-fatal coronary event by the age of 60 without effective treatment is at least $50 \%$ in men and about $30 \%$ in women. ${ }^{12}$ The prognosis has improved substantially with widespread use of statins for lipid lowering. ${ }^{3}$ The estimated occurrence of the condition is about 1 in 500. We aimed to determine the prevalence of diagnosed familial hypercholesterolaemia and to estimate the proportion of expected cases that are identified in routine clinical practice.

\section{Subjects, methods, and results}

Diagnosed patients resident in Oxfordshire were identified from the Simon Broome register of familial hyperlipidaemia, ${ }^{4}$ the Oxford lipid clinic computerised diagnostic register, and general practice records.

The Simon Broome register categorises familial hypercholesterolaemia as definite or possible. Definite familial hypercholesterolaemia is defined as total cholesterol concentration $>7.5 \mathrm{mmol} / \mathrm{l}$ in adults or $>6.7 \mathrm{mmol} / \mathrm{l}$ in children under 16 years, or low density lipoprotein cholesterol concentration $>4.9 \mathrm{mmol} / \mathrm{l}$ in adults or $>4.0 \mathrm{mmol} / \mathrm{l}$ in children, plus tendon xanthomas in the patient or a first or second degree relative. A possible diagnosis of familial hypercholesterolaemia requires cholesterol above these values, plus a family history of either a myocardial infarction before age 50 in a second degree relative or before age 60 in a first degree relative or a raised total cholesterol concentration $>7.5 \mathrm{mmol} / \mathrm{l}$ in a first or second degree relative.

The list of registered patients was cross checked against the lipid clinic computerised diagnostic register. Clinic patients found to meet the Simon Broome diagnostic criteria were registered and flagged by the NHS central registry to confirm that they were alive and resident in Oxfordshire on 30 June 1999. General practitioners were asked to notify us of the age and sex of any other affected patients (56 of 115 practices responded). The resident population was obtained from the Oxfordshire Health Authority's population estimate for 1998.

Number of cases of possible and definite familial hypercholesterolaemia and the age and sex-specific prevalence

\begin{tabular}{|c|c|c|c|c|c|c|c|c|}
\hline \multirow[b]{2}{*}{$\begin{array}{l}\text { Age } \\
\text { (years) }\end{array}$} & \multicolumn{4}{|c|}{ Males } & \multicolumn{4}{|c|}{ Females } \\
\hline & Population & $\begin{array}{l}\text { No of } \\
\text { cases }\end{array}$ & $\begin{array}{l}\text { Possible/ } \\
\text { definite* }^{*}\end{array}$ & $\begin{array}{c}\text { Prevalence } \\
\text { per } 1000\end{array}$ & Population & $\begin{array}{l}\text { No of } \\
\text { cases }\end{array}$ & $\begin{array}{l}\text { Possible/ } \\
\text { definite† }\end{array}$ & $\begin{array}{c}\text { Prevalence } \\
\text { per } 1000\end{array}$ \\
\hline $0-9$ & 41466 & 2 & $1 / 1$ & 0.05 & 39405 & 0 & 0 & 0 \\
\hline 10-19 & 41132 & 6 & $2 / 4$ & 0.15 & 38154 & 6 & $1 / 5$ & 0.16 \\
\hline $20-29$ & 45617 & 8 & $5 / 3$ & 0.18 & 43334 & 12 & $3 / 9$ & 0.28 \\
\hline 30-39 & 52578 & 23 & $12 / 9$ & 0.44 & 49857 & 19 & $10 / 7$ & 0.38 \\
\hline $40-49$ & 41505 & 35 & $21 / 11$ & 0.84 & 40409 & 29 & $17 / 11$ & 0.72 \\
\hline $50-59$ & 35114 & 45 & $21 / 18$ & 1.28 & 35982 & 31 & $17 / 10$ & 0.86 \\
\hline $60-69$ & 25319 & 28 & $21 / 6$ & 1.11 & 25651 & 47 & $31 / 15$ & 1.83 \\
\hline $70-79$ & 17512 & 15 & $4 / 10$ & 0.86 & 21972 & 25 & $15 / 10$ & 1.14 \\
\hline$\geqslant 80$ & 7109 & 0 & 0 & 0 & 14591 & 3 & $2 / 1$ & 0.21 \\
\hline All ages & 307352 & 162 & $87 / 62$ & 0.53 & 309355 & 172 & $96 / 68$ & 0.56 \\
\hline
\end{tabular}

*Excludes 13 receiving care exclusively in general practice.

†Excludes 8 receiving care exclusively in general practice.
Since 1980, 315 patients had been registered with the Simon Broome register by the Oxford lipid clinic; by 30 June 1999, 25 had died and 175 were still living in Oxfordshire. Another 167 lipid clinic patients met the diagnostic criteria, but only 138 lived in Oxfordshire; 21 other patients received care exclusively in general practice. On the basis of self reported relationships, 38 families with a total of 88 affected members were identified.

The overall prevalence was $0.54 / 1000$ (95\% confidence interval 0.48 to 0.60 ) and was highest in men aged 50-59 years and in women aged 60-69 years (table). Underdiagnosis was greatest among children and young adults: only two children under 10 years and 12 aged 10-19 years had been identified.

\section{Comment}

About a quarter of the cases of familial hypercholesterolaemia predicted were diagnosed routinely; most remained undiagnosed until middle age. The main implication of underdiagnosis is that patients are denied early treatment to reduce the risk of coronary events.

Case ascertainment should be more effective, earlier, and cost effective. ${ }^{5}$ Population based screening has not been adopted in Britain and at best would identify one case of familial hypercholesterolaemia for every 500 people screened, but it would also identify many people with polygenic hypercholesterolaemia, which is a weak predictor of coronary risk in the absence of other risk factors. The most appropriate strategies may include testing in primary care patients with early onset coronary artery disease and the children of those who die young, and family tracking using a specialist nurse to trace and test relatives of probands attending hospital lipid clinics. Systematic screening of all 16 year olds may be equally cost effective. ${ }^{5}$ The acceptability, efficacy, and cost effectiveness of these strategies must be evaluated in the United Kingdom.

Contributors: HAWN designed the study. TH and RH collected and collated data. HAWN and TH undertook the analysis and HAWN drafted the report. All authors were involved in the interpretation and critical revision of the paper, and SEH also provided specialist genetic advice. HAWN is the guarantor.

Funding: The Simon Broome Register has been funded by the British Hyperlipidaemia Association, the British Heart Foundation (grant RC 93008), the Simon Broome Heart Research Trust, and Parke Davis/Pfizer.

Competing interests: None declared.

1 Slack J. Risks of ischaemic heart disease in familial hyperlipidaemic states Lancet 1969;ii:1380-2.

2 Stone NJ, Levy RI, Fredrickson DS, Verter J. Coronary artery disease in 116 kindred with familial type II hyperlipoproteinaemia. Circulation 1974;49:476-88

3 Scientific Steering Committee on behalf of the Simon Broome Register Group. Mortality in treated heterozygous familial hypercholesterolaemia: implications for clinical management. Atherosclerosis 1999;142:105-12.

4 Goldstein JL, Hobbs HH, Brown MS. Familial hypercholesterolaemia. In: Scriver CR, Beaudet AL, Sly WS, Valle D, eds. The metabolic and molecular basis of inherited disorders. 7th ed. New York: McGraw Hill, 1995:1981-2030.

5 Marks D, Wonderling D, Thorogood M, Lambert H, Humphries S, Neil A. Screening for hypercholesterolaemia versus case-finding for familial hypercholesterolaemia: systematic review and cost effectiveness analysis. Health Technol Assessment (in press).

(Accepted 21 June 2000) 